\title{
OPTIMIZATION OF ZAKAT FUND MANAGEMENT IN REGIONAL ZAKAT INSTITUTION
}

\author{
${ }^{1 *}$ Tika Widiastuti, ${ }^{2}$ Imron Mawardi, ${ }^{3}$ Anidah Robani, ${ }^{4}$ Aam Slamet Rusydiana \\ ${ }^{1,2}$ Lecturer of Faculty of Economic and Business, Airlangga University, Surabaya \\ ${ }^{3}$ Senior Lecturer of Centre for Languages \& Human Development UniversitiTeknikal Malaysia Melaka, \\ ${ }^{4}$ Researcher of SMART Consulting Indonesia \\ tika.widiastuti@feb.unair.ac.id, ronmawardi@feb.unair.ac.id,anidah@utem.edu.my,aamsmart@gmail.com
}

Article History: Received on $05^{\text {th }}$ September, Revised on $20^{\text {th }}$ October, Published on $15^{\text {th }}$ December 2018

\begin{abstract}
Purpose: The implementation of zakat fund management especially in some zakat institutions is considered not optimum yet. This condition is represented by disparity between potential and actual collection. In Islam, the objective of zakat is not only to collect wealth and keep it idle, instead zakat should become a source of productive fund to fulfill societal needs. Some countries with advanced zakat institutions have developed zakat to become a pillar of economic development. Today, each zakat institution is competing against each other to innovate in zakat fund management. Empowerment in zakat institutions with the appropriate strategies will enhance zakat management and distribution for the betterment of zakat recipients (mustahiq) and the Muslim society at large.
\end{abstract}

Design/Methodology/Approach: This research is aimed to analyze optimization of management in regional zakat institution with SWOT (strength, weakness, opportunity, threat) analysis approach with IFE-EFE Matrix. Descriptive qualitative analysis is used to explain optimization of fund in zakat institution.

Major Findings:Findings of this research shows that zakat institution should improve their strategy by developing strength and turning threat into opportunities.

Originality/Value: The study provides a guideline for regional zakat institution on how they can enhance their role and efficiency to boost the economic growth for the Islamic community in Indonesia. It may also be instrumental for the government to improve in efficiency and innovative manpower, considerable research and development in optimizing Islamic Gift Economy to enhance economic growth of the Islamic community of Indonesia.

Keywords: Optimization, Zakat Fund Management, Islamic Economy, IFE-EFE Matrix

\section{INTRODUCTION}

Zakat is one of social instruments in Islam that is maslahah-oriented (Wahab, et al., 2011). It is a means to distribute wealth in economy, especially from the rich to the poor (Djaghballou, et, al., 2018). This fact indicates that zakat is an appropriate instrument to alleviate poverty for Muslims not only at community level but also at national level.

A country or government's role in managing zakat is very important due to urgency in distributing resources between groups and as a poverty alleviation tool.

After the enactment of Zakat Management Act No. 38 year 1999 which consists of 10 chapters and 25 articles, the Ministry of Religious Affairs established the General Directorate of Zakat and Waqf Development by the Minister of Religious Affairs Decree No. 1/2001 to strengthen zakat institution and optimize zakat management.

Besides the central government and Ministry of Religious Affairs, regional governments also accommodate the implementation of Zakat Management Act and Minister Decree to optimize regional zakat management. Cilegon City (2001), Serang Regency and East Lombok Regency (2002), Solok Regency (2003), Tangerang Regency and Banten Province (2004) are among 24 regions, two regencies, cities and provinces that have enacted Regional Regulation for Zakat according to Research and Development Division of Ministry of Religious Affairs.

Zakat management optimization depends on the performance of zakat institution management. This research is aimed to analyze fund optimization in regional zakat institutions by using a SWOT analysis.

\section{RESEARCH LITERATURE}

The term zakat is defined as paying a portion of specific assets to those who deserve it (mustahiq) in accordance with the conditions specified by Islamic law(Djaghballou, et, al., 2018). According to Act No. 23 of 2011 about zakat management, zakat is defined as a wealth that must be paid by a Muslim or a business entity to those who deserve it in accordance with Islamic law. So from the various notions of zakat, it can be concluded that the definition of zakat in general is a percentage of wealth that must be paid by a Muslim who has fulfilled the conditions to be submitted to those who deserve it.

Management of zakat in Indonesia today is mostly done by the agency or institution established directly by the government (BAZ) and the institutions set up independently by a group of people that have received mandate fromthe government (LAZ). According to the Decree of the Minister of Religion (KeputusanMenteri Agama/KMA) Chapter I of Article I / I, 
zakatis an important element of society and government have the duties of collecting, distributing and utilizing Shari'a compliant zakat for maslahahammah (common good).

In addition to zakat's attribute as a unique instrument in poverty alleviation, when done in a systematic and well organized management, it will be able to bring a multiplier effect that helps to increase the national income due to an acceleration of wealth circulation occurring in the economy.For example, Productive zakat, that given to mustahiq not for directly spending consumption purpose, can encourage mustahiq to manage and productive the wealth they have (Alfaizin, Insani, \& Herianingrum, 2018)

\section{RESEARCH METHODOLOGY}

In this research, a descriptive qualitative approach is conducted with an observational case study method. This research was conducted in zakat institutions in East Java that include Bazda JATIM (BadanAmil Zakat JawaTimur/East Java Regional Zakat Board), LMI (LembagaManajemenInfaq), YatimMandiri, LAZISMU (LembagaAmil Zakat Muhammadiyah), YDSF (Yayasan Dana Sosial Al-Falah), Al-Azhar, and BMH (BaitulMaalHidayatullah) which is centered in the city of Surabaya.

The primary data collection was done through observation, interviews, and Focus Group Discussion (FGD).The stages in this study are as follows:

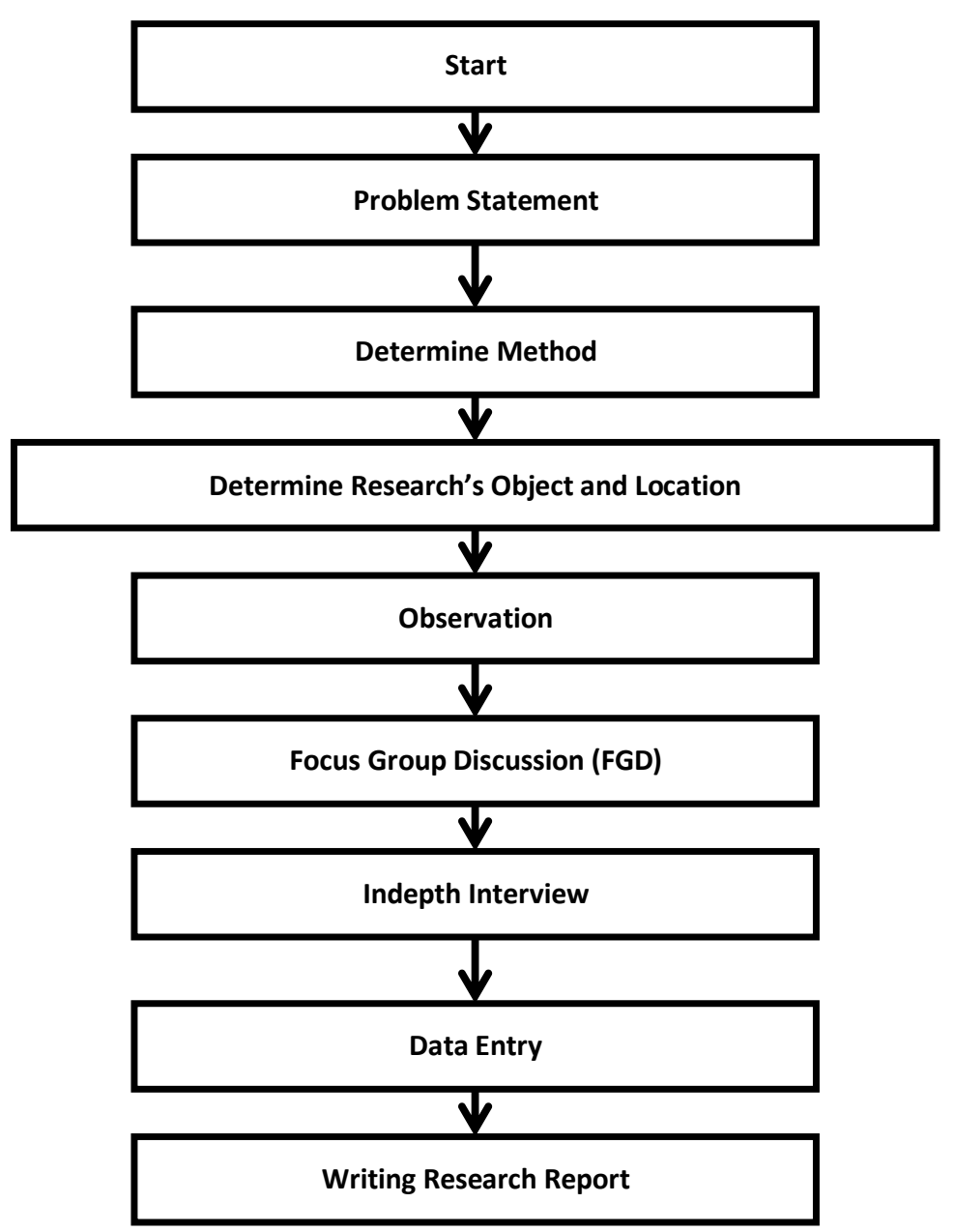

Figure 1. Study's Stages (Source: Authors' composition)

A SWOT analysis was carried out to analyze the local zakat fund management institutions in order to identify the internal factors that are regarded as strengths and weaknesses. Besides analyzing the internal factors, external factors were also analyzed.

In the SWOT analysis, activities were carried out in the following phases:

1. Identification of internal and external factors

2. Preparation for a list of questions for FGD

3. Determine respondents

4. FGD 


\section{Data Analysis}

Based on the results, perception of FGD key indicators will be obtained, which are divided into two parts: internal and external factors. The elements are identified as strengths, weaknesses, opportunities, and opportunities of stakeholders.

Expert assessment of the internal-external factors will produce clusters of factors: Strength, Weakness, Opportunity and Threat. Then, SWOT matrix analysis is conducted through interaction merger (amalgamation) of internal factors (Strength, Weakness), with external factors (Opportunity, Threat).

In the analysis of SWOT matrix interactions, incorporation of strategies including a combination of internal-external interaction strategies consists of:

a. SO (Strength-Opportunity) Strategy: create strategies to use strength as a way to take advantage of opportunities

b. ST (Strength-Threat) Strategy: create strategies to address the threat by using strength

c. WO (Weakness-Opportunity) Strategy: create strategies that minimize weaknesses to create opportunities.

d. WT (Weakness-Threat) Strategy: create strategies that minimize weaknesses to overcome the threat.

Before creating the matrix interaction strategy of external and internal factors (EFAS-IFAS), the decision making process should follow the steps below (Rangkuti, 2002):

a. External Factor Analysis Strategy (EFAS)

The stages in the development of EFAS matrix are:

1) Make strategic external environment factors that includes: opportunities and threats.

2) Determine strategic weighting factor on a scale from 0.0 (not important) to 1.0 (very important). The weights indicate the interest rate factor to the success of institutions / agencies.

3) Provide strategic factor rating with a scale ranging from 1 (poor) to 4 (outstanding) based on the influence of these factors to the conditions of the enterprise.

4) Multiply the weight by the rating to obtain the value of the weighting factor.

5) Add up the value of the weighting of the column to get the total score for the company concerned. Total scores can be used to compare management of a zakat institution with other zakat institutions.

b. Internal Factor Analysis Strategy (IFAS)

The development stages of IFAS matrix are:

1) Making strategic internal environment factor that includes: strength (strength) and weakness (weaknesses).

2) Determination of strategic weighting factor on a scale from 0.0 (not important) to 1.0 (very important), based on the influence of these factors on the strategic position of zakat institutions management (all weights may not exceed a total score of 1.0).

3) Providing strategic factor rating with a scale ranging from 1 (poor) to 4(outstanding) based on the influence of the these factors to the condition of the company concerned. Multiply the weight by the rating to gain weighting factors.

4) Add up the value of each valued columns to get the total score for the company concerned. Total scores can be used to compare the company with other companies in the same industry group.

\section{RESULT}

In the economy, zakat is related to the nature of worship. It is important that zakat assists in changing the status quo of the poor families(Abdul-Majeed Alaro \& Alalubosa, 2018; Abdullah, Mat Derus, \& Al-Malkawi, 2015; Ahmed, Johari, \& Abdul Wahab, 2017; Al-Malkawi \& Javaid, 2018; Mariyanti \& Mahfudz, 2016; Saad \& Farouk, 2019).Another effect of zakat is transformation of character (Shaikh, et. al., 2017). At the time of the Prophet, he directed the Muslims to be healthy and fit, not for begging but, to work hard. The role of Zakat will be maximal in moving the economy if there is synergy between the stakeholders of zakat.

Based on the results of FGD with BAZ and LAZ in East Java, a SWOT analysis of BAZ and LAZ in East Java suggests:

Strength: LAZ as a social institution also serves to accommodate the need of the muzakki, which is part of their social obligation, so that the intention of muzakki becomes clear and the mustahiq can be empowered through empowerment programs. Zakat as a core competence is also the main activity for LAZ dan BAZ. Both serve to empower those who are socially and economically poor as well as in cultivating noble social morale. 
Weakness: A number of weaknesses are first is the consolidation between BAZ and LAZ and between instruments. The second problem is the time lag between payment of zakat funds to the distribution of zakat (even though this is one of their ways to utilize zakat funds in order to provide a more optimum impact for mustahiq, however it still become a problem). LAZ's inefficient performance is due to the quality of human resources which is still not ideal.

Opportunity: The huge size of the Muslim population in Indonesia certainly holds potential for a huge collection of zakat for BAZ and LAZ. In addition, LAZ is also supported by public awareness which encourage people to start paying their zakat via LAZ. Another opportunity that can be optimized by LAZ is the emergence of information technology to facilitate the public transaction.

Threat: The first threat is friction among Muslims in understanding the practices of zakat which is considered not optimum because of different opinions and practices of non-profit institutions of Islam. For LAZ, the government is also inefficient in educating people to pay zakat through official institutions

Based on the results of SWOT analysis above, it can be concluded that the internal conditions that are regarded as strengths of BAZ and LAZ in Surabaya lies on two sides:

1. For LAZ, its main strength is the hallmark of every LAZ. that unique and different among them, and it is reflected in every segmentation and diversification program so that each specializes in a particular field in zakat.

2. For BAZ, its main strength lies in its institutional aspects which are supported by legislation and the discretion of the provincial government and the Ministry of Religious Affairs.

Moreover, BAZ and LAZ in East Java have a great opportunity to develop in the future because there are some supporting external situations as follows:

1. The number of large Muslim population shows great potential and also great muzakki /mustahiq program objectives.

2. Islamic lifestyle and information technology development at this time can be a tool for BAZ and LAZ to grow exponentially.

3. $\mathrm{BAZ}$ is the coordinator for LAZ and the presence of Zakat Forum (FOZ) makes the collaboration between ameelzakat become possible.

However, a number of weaknesses were shown by BAZ and LAZ in the management of zakat. These are driven by at least three main factors:

1. The lack of understanding between the Islamic philanthropy instruments (zakat, donation and endowments) in LAZ and BAZ and their collaboration with ameelzakat.

2. Low quality of services as a result of the low academic qualification of human resources working in BAZ and LAZ

3. The absence of valid data on the quantity and distribution of muzakki and mustahiqcomplicates BAZ and LAZ's task in formulating programs and management of zakat.

Based on the exposure conditions / SWOT analysis above, there are a number of findings which are the basis for BAZ / LAZ strategic planning in order to optimize the management of Zakat. These are mentioned below:

1. Basically, every ameelzakat in both BAZ and LAZ has the characteristics that can become a major force in each individual institution. However, they need to collaborate to optimize the potential of the entire ameelzakat in aggregate.

2. The collaboration can be done by sharing experiences between LAZ and BAZ programs and mapping the conditions of muzakki and mustahiq fostered by ameelzakat.

3. Policy on Human Resources Development in the field of ameel needs a special attention.

4. LAZ and BAZ together, either through coordination from BAZ or FOZ, should encourage the government to enforce and evaluate legislation and promote education so that zakat managed by BAZ and LAZ can be optimally managed and supported by a wider community.

Strategic factor evaluation, which consists of Internal Factor Evaluation (IFE) andExternal Factor Evaluation (EFE), can be conducted by giving weight and rank values to each internal factors (strengths and weaknesses) and external factors (opportunities and threats).

\section{Internal Factor Evaluation (IFE)}


IFE is the weighting and ranking performed by the respondents on each factor in strength and weakness. Result of internal factor evaluation can be seen in table 1. From the table, it can be seen that the internal strength factor (Strength) with highest degree of importance is institutional support especially for the BAZ with the value of 0.133 . Then, it is followed by the factor of "each institution of zakat has its own segmentation in the minds of community" with an average value of 0.116. Meanwhile, "the experience factor owned by long standing zakat institution" is a factor that has the lowest importance of the zakat institution's strength with an average value 0.115 .

Table 1: IFE - EFE Assessment

\begin{tabular}{|l|l|l|l|}
\hline Internal Factors Evaluation (IFE) & Weight & Rating & Weight*Rating \\
\hline Strengths & & & 1.136 \\
\hline 1) Segmentation of each LAZ & 0.116 & 3.0 & 0.347 \\
\hline 2) Experience from long standing LAZ & 0.115 & 3.4 & 0.390 \\
\hline 3) Institutional support especially for BAZ & 0.133 & 3.0 & 0.399 \\
\hline Weaknesses & & & 2.102 \\
\hline 1) LAZ-BAZ Consolidation & 0.115 & 3.2 & 0.369 \\
\hline 2) Inter-program synergy & 0.116 & 2.6 & 0.301 \\
\hline 3) Time interval for zakat fund to reach mustahiq/beneficiaries & 0.127 & 3.6 & 0.459 \\
\hline 4) HR condition in zakatamil & 0.139 & 3.4 & 0.473 \\
\hline 5) Muzakki-mustahiq data validity & 0.139 & 3.6 & 0.499 \\
\hline TOTAL & 1.000 & & 3.238 \\
\hline External Factors Evaluation (EFE) & Weight & Rating & Weight*Rating \\
\hline Opportunities & & & 2.238 \\
\hline 1) Muslim majority population in Indonesia & 0.129 & 3.8 & 0.488 \\
\hline 2) Program innovation for unbankablemustahiq & 0.122 & 3.6 & 0.439 \\
\hline 3) Optimization of IT & 0.134 & 3.4 & 0.454 \\
\hline 4) Development of Islamic lifestyle & 0.116 & 3.4 & 0.395 \\
\hline 5) FOZ as communication hub for ameel & 0.128 & 3.6 & 0.461 \\
\hline Threats & & & 1.017 \\
\hline 1) Society's different opinions regarding zakat & 0.122 & 2.8 & 0.342 \\
\hline 2) LAZ-BAZ lack of understanding on community's needs & 0.127 & 3.0 & 0.381 \\
\hline 3) Lack of government support for BAZ-LAZ & 0.123 & 2.4 & 0.294 \\
\hline TOTAL & 1.000 & & 3.255 \\
\hline
\end{tabular}

Sources: Authors' analysis by using excel 2013

For weakness factors, the highest scored factors are condition of zakat human resources and the muzakki-mustahiq data validity with the same weight of 0.139 . The next factor is related to the time interval of zakat fund channeled to mustahiq at 0.127 . The IFE analysis results also show that the assessment of the current condition of LAZ's long standing experience factor, ranked first with a value of 3.4. While the other two power factors, LAZ segmentation and institutional support each has a value of 3.0. This indicates experience factor is the most dominant factor for an ameel.

Furthermore, it is also known from the weaknesses that the muzakki-mustahiq data validity and time interval of zakat funds to mustahiq has the highest rating of 3.6 which means this factor has a negative impact on the optimization of zakat fund management. Furthermore, the condition of human resources (HR)zakatameel (3.4) and consolidation between LAZ and BAZ (3.2) have considerable influence. The synergy between programs owned by LAZ (2.6) is considered as not having a negative impact on the optimization of zakat fund management in general.

\section{Evaluation of External Factors (EFE)}

EFE is the weighting and rating given by respondents on each opportunity and threat factor. The result of external factor evaluation can be seen in table 1. From the table, it can be seen that external factor with the highest degree of importance is "optimization of information technology (IT)" with an average weight of 0.134 . This is followed by "Muslim majority population of Indonesia" factor (0.129) and "FOZ as a communication hub between ameels" (0.128). The last two factors, the programme innovation for unbankablemustahiq (0.122) and the development of Islamic lifestyle (0.116)-, are considered to have little importance in optimizing management of zakat funds.

At the same time, the highest degree of importance for threat factor is "LAZ-BAZ lack of understanding on community's needs" (0.127) followed by "lack of government support for BAZ-LAZ" factor (0.123) and "society's different opinions regarding zakat" (0.122). Ideally, it is very important for LAZ / BAZ to understand the needs of the community(Wahab, et al., 2011).

Furthermore, current condition shows that from the aspect of opportunity, the "Muslim majority population in Indonesia" has the highest rating with a score of 3.8 which means it has the greatest influence as an opportunity factor in optimizing 
the management of zakat funds. "Program innovation for unbankablemustahiq" and "FOZ as a communication hub for ameel" (3.6) are ranked second and third. The "optimization of IT" and "development of Islamic lifestyle" only have value 3.4 each. IT optimization is very important to enable optimum management of zakat in Indonesia. However, the results of this study show that in fact the current condition, the use of IT to support LAZ / BAZ is still not optimal (value 3.4) while on the other hand, the respondents viewed the importance of optimizing IT (0.134). Optimizing IT will improve the efficiency of the institutions and grows the community trust through reliable reporting (Owolaby Yusuf, 2013).

From the side of the threat, "LAZ-BAZ lack of understanding on community's needs" factor has the highest rating of 3.0 which means it is the highest factor in inhibiting the optimization of zakat fund management. Then, the second rank factor is the "different opinions regarding zakat"(2.8) and "the lack of government support for LAZ / BAZ" (2.4). The following table shows IFE-EFE assessment to optimize zakat fund management.

After evaluating the said strategic factors, then IFE-EFE quadrant determines the position assessment for optimizing zakat management in Indonesia. Assessment of internal factor evaluation (IFE) is 3.238 and external factor is 3.255. This value is in quadrant I that means "grow and develop". This shows that the existence of zakat fund management in Indonesia is experiencing a growth stage and must be improved because it has huge potential to be developed. The existence of internal and external factors basically becomes a huge support for the optimization of zakat fund management in general (Menne, 2016; Mariyanti, 2016).

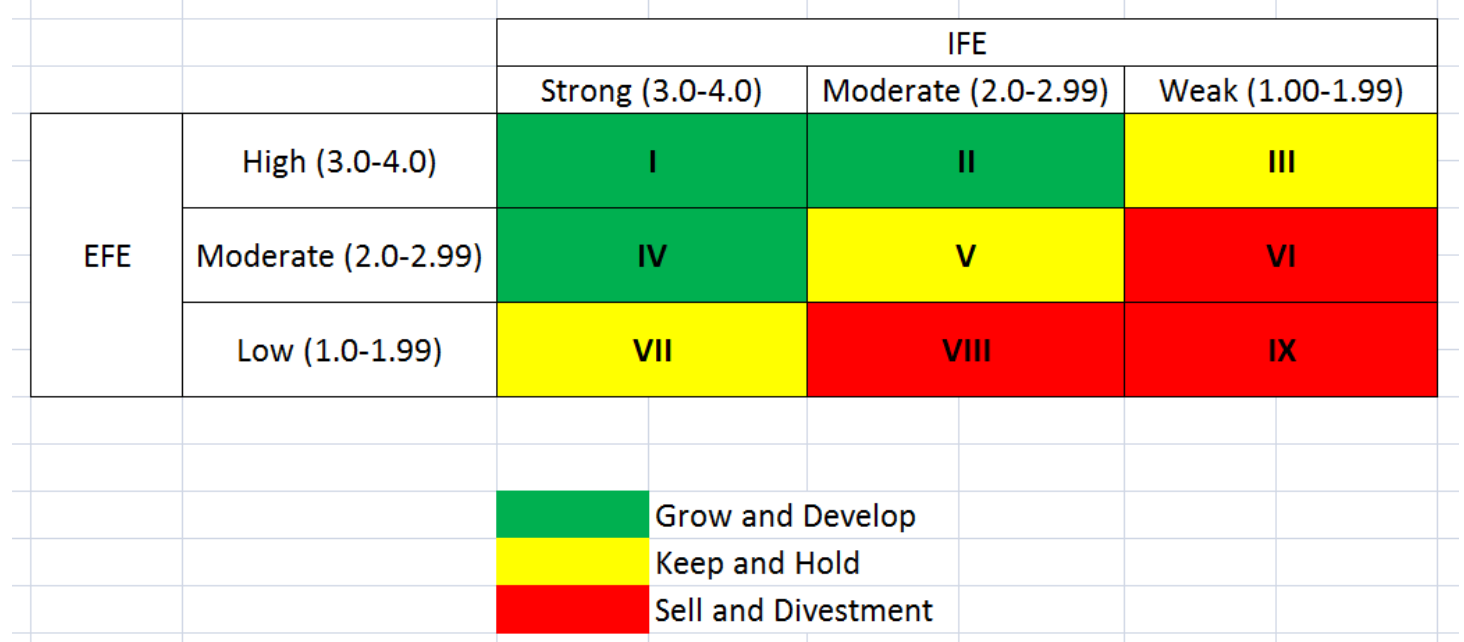

Figure 2 IFE - EFE Matrix Quadrant (Sources: David (2011)

\section{CONCLUSION}

Based on the results of SWOT Analysis, a number of factors has been identified contributing positively towards BAZ and LAZ's zakat management by in East Java. Internal supporting factors or the strengths are the segmentation and experience from long-established LAZ and the institutional support to BAZ. Meanwhile, external factors that provide opportunities to BAZ and LAZ's zakat management are are the Muslim majority population, the rise of Islamic lifestyle and information technology. However, aspects of the synergy between BAZ and LAZ, low quality of human resources, lack of data on mustahiq and muzakki and lack of government support is still minimal for ameelzakat management. Assessment on IFE and EFE results in optimizing zakat fund shows IFE scored 3.238 and EFE scored 3.255. This combination is positioned in quadrant I which means "grow and develop." This condition refers to zakat fund management in Indonesia which is currently under development and must be improved due to the huge potential to be further developed.

\section{LIMITATION AND STUDY FORWARD}

This study is limited to the analyses of the management of Zakat institutions using qualitative approach of IFE and EFE, and the scope of this research is only in the region of East Java. However, the results of this study can provide practical guidance for regional zakat institutions on how they can improve their role and efficiency. In addition, if the results of this study are able to increase economic growth for the Islamic community, it can be used as a method to assess institutions in other locations, both in Indonesia and in other countries by future researchers.

\section{ACKNOWLEDGEMENT}

Authors would like to express gratitude to the Faculty of Business and Economics and its Research and Innovation centre for providing the support on this research by providing financial support and data so that this research can be carried out to completion. Further, Authors would like to acknowledge the reviewers for their comments and advises to improve this research. 


\section{REFERENCES}

1. Abdul-MajeedAlaro, A. and Alalubosa, A. H. (2018) 'Potential of Sharī'ah compliant microfinance in alleviating poverty in Nigeria: A lesson from Bangladesh', International Journal of Islamic and Middle Eastern Finance and Management. Emerald Publishing Limited.

2. Abdullah, N., Mat Derus, A. and Al-Malkawi, H.-A. N. (2015) 'The effectiveness of zakat in alleviating poverty and inequalities: a measurement using a newly developed technique', Humanomics. Emerald Group Publishing Limited, 31(3), pp. 314-329.

3. Ahmed, B. O., Johari, F. and Abdul Wahab, K. (2017) 'Identifying the poor and the needy among the beneficiaries of zakat: Need for a zakat-based poverty threshold in Nigeria', International Journal of Social Economics. Emerald Publishing Limited, 44(4), pp. 446-458.

4. Al-Malkawi, H.-A. N. and Javaid, S. (2018) 'Corporate social responsibility and financial performance in Saudi Arabia: Evidence from Zakat contribution', Managerial Finance. Emerald Publishing Limited, 44(6), pp. 648-664.

5. Alfaizin, A. W., Insani, T. D. and Herianingrum, S. (2018) Zakat: Concept and Implications to Social and Economic (Economic TafsīrOf Al-Tawbah: 103), Journal of Islamic Monetary Economics and Finance, 4(1), pp. 117-132.

6. David, F., (2011), Strategic Management, ManajemenStrategis, Konsep. Jakarta: SalembaEmpat.

7. Djaghballou,Chams-Eddine, Mohamed Djaghballou, MousaLarbani, AzharMohamad, (2018) "Efficiency and productivity performance of zakat funds in Algeria", International Journal of Islamic and Middle Eastern Finance and Management, Vol. XI(3), 474-494, https://doi.org/10.1108/IMEFM-07-2017-0185

8. Mariyanti, T., \&Mahfudz, A. A. (2016). Dynamic circular causation model in poverty alleviation: Empirical evidence from Indonesia. Humanomics, 32(3), 275-299.

9. Menne, F. (2016). Evidence of CSR Practices of Islamic Financial Institutions in Indonesia. In Advances in Islamic Finance, Marketing, and Management: An Asian Perspective (pp. 341-362). Emerald Group Publishing Limited.

10. Owolabi Yusuf, M. B., \& Mat Derus, A. (2013). Measurement model of corporate zakat collection in Malaysia: A test of diffusion of innovation theory. Humanomics, 29(1), 61-74.

11. Saad, R. A. J. and Farouk, A. U. (2019) 'A comprehensive review of barriers to a functional Zakat system in Nigeria: What needs to be done?'International Journal of Ethics and Systems. Emerald Publishing Limited, 35(1), pp. 24-42.

12. Shaikh, S. A., Ismail, M. A., Ismail, A. G., Shahimi, S., \&Mohd. Shafiai, M. H. (2017). Towards an integrative framework for understanding Muslim consumption behaviour. Humanomics, 33(2), 133-149.

13. Wahab, N. A., \& Rahim Abdul Rahman, A. (2011). A framework to analyse the efficiency and governance of zakat institutions. Journal of Islamic Accounting and Business Research, 2(1), 43-62.

14. YatimMandiri. (2012). Tentang Kami, (Online), (http://www.yatimmandiri.org/tentangkami/. Diaksespada 8 April 2013). 